Check for updates

Cite this: Chem. Sci., 2019, 10, 9130

๑ All publication charges for this article have been paid for by the Royal Society of Chemistry

Received 4th July 2019

Accepted 14th August 2019

DOI: $10.1039 / c 9 s c 03324 f$

rsc.li/chemical-science

\section{Silicon clusters with six and seven unsubstituted vertices via a two-step reaction from elemental silicontt:}

\author{
Lorenz J. Schiegerl, ${ }^{\text {ab }}$ Antti J. Karttunen, (D) ${ }^{c}$ Wilhelm Klein (1D) ${ }^{a}$ \\ and Thomas F. Fässler (D) *ab
}

\begin{abstract}
Unsaturated silicon clusters with only partial substitution, and thus, "naked" Si atoms are well studied species as they are proposed intermediates in gas-phase deposition processes. Although a remarkable number of stable molecular clusters has been reported, they are typically still obtained by multi-step syntheses. Herein we introduce a newly developed synthetic approach which led to the formation of the anionic species $\left\{\mathrm{Si}(\mathrm{TMS})_{3}\right\}_{3} \mathrm{Si}_{9}{ }^{-}(1 \mathrm{a})$ and $\left\{\mathrm{Si}(\mathrm{TMS})_{3}\right\}_{2} \mathrm{Si}_{9}{ }^{2-}(1 \mathrm{~b})$, and an extension of this synthetic protocol resulted in the first covalent attachment of ligands through metal atoms to these clusters, $\left(\mathrm{SnCy}_{3}\right)_{3} \mathrm{Si}_{9}{ }^{-}(2 \mathrm{a})$ and $\left(\mathrm{SnCy}_{3}\right)_{2} \mathrm{Si}_{9}{ }^{2-}(2 \mathrm{~b})$. The influence of the substituents on the electron localization in the central $\mathrm{Si}_{9}$ unit is analyzed by means of intrinsic bond orbital (IBO) analysis and partial atomic charge distribution. The IBO analyses reveal a new type of delocalization including 5-center-6-electron besides 3-center-2-electron bonds. The Raman spectra of $1 \mathrm{~b}$ and $2 \mathrm{~b}$ allow an assignment of the $\mathrm{Si}-\mathrm{Si}$ intra-cluster vibrations by comparison to calculated (DFT-PBE0) spectra. The anions are formed in a one-step synthesis from binary $\mathrm{K}_{12} \mathrm{Si}_{17}$ which can easily be obtained by fusing the elements $\mathrm{K}$ and $\mathrm{Si}$. The anions are characterized by ESI mass spectrometry and comprehensive NMR studies $\left({ }^{1} \mathrm{H},{ }^{13} \mathrm{C},{ }^{29} \mathrm{Si},{ }^{119} \mathrm{Sn}\right)$. Attempts to crystallize 1a and $2 \mathrm{a}$ as their $(\mathrm{K}-222 \mathrm{crypt})^{+}$salts yielded after the loss of one of the substituents single crystals containing $1 \mathrm{~b}$ and $2 \mathrm{~b}$. The single crystal $\mathrm{X}$-ray structure analyses reveal the presence of anionic siliconoids with surfaces of seven unsubstituted silicon atoms.
\end{abstract}

\section{Introduction}

The call for new sources of silicon-based materials is steadily increasing due to applications in numerous daily-life products as e.g. batteries, photovoltaics and electronic devices. ${ }^{1-8}$ The wide range of applications is promoted by the abundancy, low costs, non-toxicity and semiconducting properties of silicon. After the first reports on $\mathrm{Si}=\mathrm{Si}$ double bonds ${ }^{9,10}$ a new field for the exploration of tailor-made low-valent silicon compounds has been established that undergoes constant expansion, mirrored e.g. by the synthesis of stable silaethenes $\left(\mathrm{SiMe}_{3}\right)_{2} \mathrm{Si}=$ $\mathrm{C}\left(\mathrm{OSiMe}_{3}\right) \mathrm{R}\left(\mathrm{R}=\right.$ adamantyl, $\left.\mathrm{CEt}_{3}, \mathrm{CMe}\right){ }^{11,12}$ compounds with silicon-silicon triple bonds as in $\left({ }^{\mathrm{i}} \mathrm{PrR}_{2}{ }_{2}\right) \mathrm{Si}-\mathrm{Si} \equiv \mathrm{Si}-\mathrm{Si}\left(\mathrm{R}_{2}^{\prime}{ }_{2}^{\mathrm{i}} \mathrm{Pr}\right)\left(\mathrm{R}^{\prime}\right.$ $\left.=\mathrm{CH}\left(\mathrm{SiMe}_{3}\right)_{2}\right),{ }^{13}$ a stable silylene $(\mathrm{CH})_{2}\left(\mathrm{NC}\left(\mathrm{CH}_{3}\right)_{3}\right)_{2} \mathrm{Si}^{14}{ }^{14}$ an

\footnotetext{
${ }^{a}$ Department of Chemistry, Technische Universität München, Lichtenbergstraße 4, 85748 Garching, Germany. E-mail: thomas.faessler@lrz.tum.de

${ }^{b}$ WACKER Institute of Silicon Chemistry, Technische Universität München, Lichtenbergstraße 4, 85748 Garching, Germany

${ }^{c}$ Department of Chemistry and Materials Science, Aalto University, 00076 Aalto, Finland

$\dagger$ Dedicated to Professor Reinhold Tacke on the occasion of his $70^{\text {th }}$ birthday.

\$ Electronic supplementary information (ESI) available. CCDC 1896557 and 1896556. For ESI and crystallographic data in CIF or other electronic format see DOI: $10.1039 / \mathrm{c} 9 \mathrm{sc} 03324 \mathrm{f}$
}

aromatic hexasilabenzene isomer $\left(\mathrm{Tip}_{6} \mathrm{Si}_{6}\right.$ (Tip $=2,4,6$-triisopropylphenyl), ${ }^{15}$ the triatomic $\mathrm{Si}(0)$ unit $(\mathrm{CAAC})_{3} \mathrm{Si}_{3}$ (CAAC $=$ cyclic (alkyl)amino carbene) ${ }^{16}$ and of so-called siliconoid clusters. ${ }^{17-21}$ Siliconoids are best described as partially substituted silicon clusters with ligand-free silicon atoms (Fig. 1), and further modifications of such silicon compounds have frequently been achieved, which underlines their versatile synthetic potential for the formation of silicon-based materials. ${ }^{19-27}$

Their synthesis has made major progress in recent years, and just lately a step-wise, atomically precise expansion of the anionic siliconoid (Tip) $\mathrm{Si}_{6}{ }^{-}$(Fig. 1b) was reported using $(\mathrm{Cp})_{2} \mathrm{Si}^{31}$ The formation of siliconoids of higher nuclearity from molecular precursors, however, generally affords several synthetic steps. In 1993, Wiberg et al. already suggested in their report on the synthesis of $\left(\mathrm{Si}^{t} \mathrm{Bu}_{3}\right)_{4} \mathrm{Si}_{4}$ that such substituted $\mathrm{Si}_{4}$ cluster compounds should probably be accessible in a more straightforward manner through the reaction of alkyl halides with tetrahedral $\mathrm{Si}_{4}{ }^{4-}$ polyanions that occur in binary alkali metal alloys of silicon. ${ }^{32}$ This idea was promoted by subsequent reports on $\left(\mathrm{SiMeDis}_{2}\right)_{3} \mathrm{Si}_{4}{ }^{-}\left(\mathrm{Dis}=\mathrm{CH}\left(\mathrm{SiMe}_{3}\right)_{2}\right)^{28}$ (Fig. 1a) and $\left(\mathrm{Si}^{t} \mathrm{Bu}_{3}\right)_{3} \mathrm{Si}_{4}{ }^{-}$(ref. 33) in which - again via molecular precursors - tri-substituted tetrahedral $\mathrm{Si}_{4}$ clusters have been obtained. The idea of using Zintl anions as precursors for Si-rich 
a)

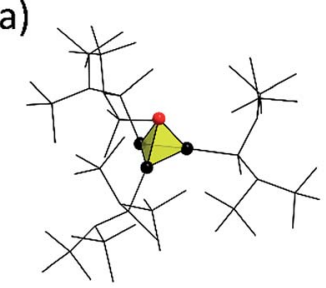

c)

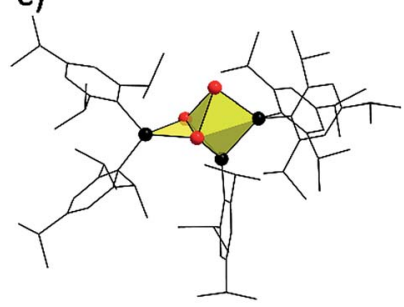

e)

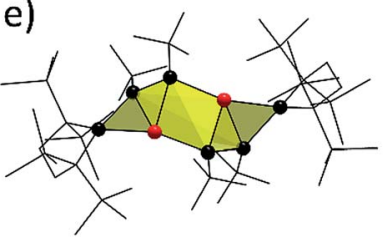

b)

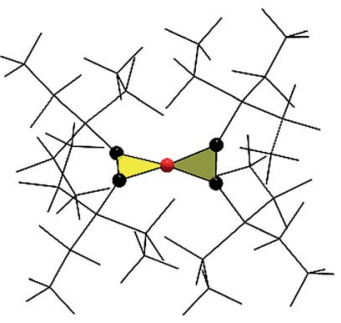

d)

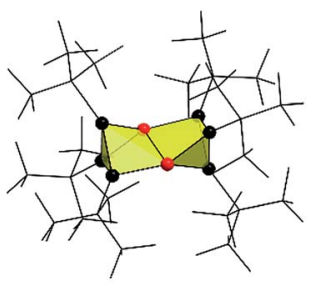

f)

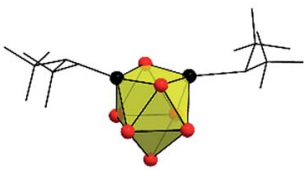

Fig. 1 Selected examples of known molecular silicon cluster species with naked cluster atoms: (a) $\left(\mathrm{SiMeDis}_{2}\right)_{3} \mathrm{Si}_{4}{ }^{-}\left(\mathrm{Dis}=\mathrm{CH}\left(\mathrm{SiMe}_{3}\right)_{2}\right) ;{ }^{28}$ (b) $\left\{\mathrm{Si}\left(\mathrm{SiMe}^{t} \mathrm{Bu}_{2}\right)_{3}\right\}_{4} \mathrm{Si}_{5}{ }^{29}$ (c) the siliconoid (Tip) ${ }_{5} \mathrm{Si}_{6}{ }^{-}$(Tip $=2,4,6$-triisopropylphenyl):i8 (d) $\left(\mathrm{Si}^{t} \mathrm{Bu}_{3}\right)_{6} \mathrm{Si}_{8}{ }^{21}$ (e) $\left({ }^{t} \mathrm{Bu}\right)_{4}\left\{\mathrm{C}_{4}\left(\mathrm{SiMe}_{3}\right)_{4}\right\}_{2} \mathrm{Si}_{8}{ }^{20}$ (f) the siliconoid $\left(\mathrm{SiH}^{\mathrm{t}} \mathrm{Bu}_{2}\right)_{2} \mathrm{Si}_{9}{ }^{2-}(3 \mathrm{~b}){ }^{30}$ Silicon clusters are shown as yellow polyhedra; naked and substituted Si cluster atoms are shown as red and black spheres, respectively, and the cluster substituents are drawn in the wire-and-stick mode.

molecules has constantly been pursued for more than two decades, nevertheless, many approaches were repeatedly discarded due to the high reducing properties of such silicides. ${ }^{19,32}$

Examples of Zintl phases with deltahedral clusters are $\mathrm{A}_{4} \mathrm{Si}_{4}$ (ref. 34-37) $(\mathrm{A}=\mathrm{Li}-\mathrm{Cs})$ and $\mathrm{A}_{12} \mathrm{Si}_{17}$ (ref. 38 and 39) $(\mathrm{A}=\mathrm{K}-\mathrm{Cs})$, which contain solely $\mathrm{Si}_{4}{ }^{4-}$ units and $\mathrm{Si}_{4}{ }^{4-}$ alongside $\mathrm{Si}_{9}{ }^{4-}$ in a 2:1 ratio, respectively. The $\mathrm{Si}_{4}{ }^{4-}$ and $\mathrm{Si}_{9}{ }^{4-}$ clusters are unsaturated species with interesting properties firstly due to their nucleophilic character (multiple negative charge). Secondly, they are electrophilic in character at the same time due to an electron-deficient bonding situation of the cluster skeleton. ${ }^{40,41}$ Since the $\mathrm{A}_{4} \mathrm{Si}_{4}$ phases are rather insoluble in any solvent, the focus was set on the $\mathrm{A}_{12} \mathrm{Si}_{17}$ phases which are soluble in liquid ammonia, from which solvates containing $\mathrm{Si}_{4}{ }^{4-}$ (ref. 42 and 43) and $\mathrm{Si}_{9}{ }^{4-}$ (ref. 43-45) units could be obtained, and it has been shown that the $\mathrm{Si}_{4}{ }^{4-}$ Zintl clusters from such an $\mathrm{A}_{12} \mathrm{Si}_{17}$ phase are receptive to chemical conversion. (CuMes) ${ }_{2} \mathrm{Si}_{4}{ }^{4-}$ (ref. 46) was obtained by the reaction with CuMes (Mes $=1,3,5$-trimethylbenzene). But also the $\mathrm{Si}_{9}{ }^{4-}$ clusters could be derivatized e.g. by the addition of transition metal fragments yielding $(\mathrm{PhZn}) \mathrm{Si}_{9}{ }^{3-}{ }^{47}{ }^{47}\left(\left\{\mathrm{Ni}(\mathrm{CO})_{2}\right\}_{2} \mathrm{Si}_{9}\right)_{2}{ }^{8-}$ (ref. 48) and $\left(\mathrm{NHC}^{\mathrm{Dipp}} \mathrm{Cu}\right) \mathrm{Si}_{9}{ }^{3-}\left(\mathrm{NHC}^{\mathrm{Dipp}}=1,3\right.$-bis-(2,6-di-iso-propylphenyl) imidazole-2-ylidene). ${ }^{49}$

However, a synthetic approach including $\mathrm{Si}_{4}{ }^{4-}$ or $\mathrm{Si}_{9}{ }^{4-}$ units to form covalent bonds to ligands is still missing, although such reactions of the corresponding $\mathrm{Ge}_{9}{ }^{4-}$ clusters (from the precursor Zintl phase $\left.\mathrm{K}_{4} \mathrm{Ge}_{9}\right)^{50-53}$ are very well known. Investigations on the solubility of the silicon clusters in $\mathrm{A}_{12} \mathrm{Si}_{17}$ revealed that in liquid ammonia solution the mono-protonated species $\mathrm{HSi}_{9}{ }^{3-}$ (ref. 45 and 54) is present, and that a subsequent transfer to pyridine yields even the doubly-protonated species $\mathrm{H}_{2} \mathrm{Si}_{9}{ }^{2-}{ }^{2.5}$ Furthermore, theoretical studies suggest the formation of siliconoids with $\mathrm{Si}_{9}{ }^{4-}$ units by the attachment of $\mathrm{sp}^{3}$-Si linkers. ${ }^{56}$ Just recently, we used $\mathrm{Si}_{9}$ clusters from the precursor $\mathrm{K}_{12} \mathrm{Si}_{17}$ for the production of the anionic siliconoids $\left(\mathrm{SiH}^{t} \mathrm{Bu}_{2}\right)_{3} \mathrm{Si}_{9}{ }^{-}(\mathbf{3 a})$ and $\left(\mathrm{SiH}^{t} \mathrm{Bu}_{2}\right)_{2} \mathrm{Si}_{9}{ }^{2-}$ (3b, Fig. 1d) via direct ligand attachment. ${ }^{30}$ The silylation of $\mathrm{Si}_{9}$ clusters by the reaction of $\mathrm{K}_{12} \mathrm{Si}_{17}$ with $\mathrm{SiH}^{t} \mathrm{Bu}_{2} \mathrm{Cl}$ yields species with covalently bonded $\mathrm{SiH}^{t} \mathrm{Bu}_{2}$ groups at the cluster vertex atoms. These siliconoids contain the so far highest number of unsubstituted silicon atoms (six in $\mathbf{3 a}$ and seven in 3b) and are more easily accessible than those siliconoids obtained via the established "molecular multi-step" approaches. By a recent definition of siliconoids, ${ }^{19}$ the unsubstituted $\mathrm{Si}$ atoms only display homoatomic bonds with a hemispheroidal coordination sphere and are free of ligands. Herein we report on the reactivity of $\mathrm{K}_{12} \mathrm{Si}_{17}$ towards $\mathrm{SiTMS}_{3} \mathrm{Cl}$ and $\mathrm{SnCy}_{3} \mathrm{Cl}$ (TMS $=$ trimethylsilane, $\mathrm{Cy}=$ cyclohexyl).

\section{Results and discussion}

The recently introduced synthetic route for the formation of anionic siliconoids by substitution of $\mathrm{Si}_{9}$ clusters from $\mathrm{K}_{12} \mathrm{Si}_{17}$ was further explored employing $\mathrm{SiTMS}_{3} \mathrm{Cl}$ and $\mathrm{SnCy}_{3} \mathrm{Cl}$ as reagents. Reactions of $\mathrm{Ge}_{9}$ clusters from the $\mathrm{K}_{4} \mathrm{Ge}_{9}$ precursor with such reactants led to an attachment of silyl ${ }^{51,57-61}$ and stannyl ${ }^{62,63}$ groups at the cluster cores, and the products were characterized as tri-substituted cluster species by ESI-MS and NMR investigations in solution as well as by X-ray analysis in solid-state. Regarding the corresponding reaction of $\mathrm{Si}_{9}$ clusters from $\mathrm{K}_{12} \mathrm{Si}_{17}$ in solution, an "activation" of the precursor by liquid $\mathrm{NH}_{3} / 222$ crypt $^{30,55}$ has been found to be a key-step. The silylation of $\mathrm{Si}_{9}$ was accomplished by the reaction of $\mathrm{K}_{12} \mathrm{Si}_{17}$ after pretreatment with liquid $\mathrm{NH}_{3} / 222 \mathrm{crypt}^{30}$ with $\mathrm{Si}(\mathrm{TMS})_{3} \mathrm{Cl}$ and $\mathrm{SnCy}_{3} \mathrm{Cl}$ in thf and pyridine, respectively, and yielded deep brownish filtrates which were dried in vacuo. Digesting the residue with fluorobenzene, decanting of the solutions, and removal of all volatile ingredients yielded bulk materials which were further characterized by ESI-MS and NMR spectroscopy $\left({ }^{1} \mathrm{H},{ }^{13} \mathrm{C},{ }^{119} \mathrm{Sn},{ }^{29} \mathrm{Si}\right)$.

The ESI-MS spectrum of the reaction product with $\mathrm{SiTMS}_{3} \mathrm{Cl}$ shows the mass peak of the tri-silylated species $\left\{\mathrm{Si}(\mathrm{TMS})_{3}\right\}_{3} \mathrm{Si}_{9}{ }^{-}$ (1a) as single species (Fig. 2a). Fragmentation of the isolated mass peak leads to the corresponding di- and mono-silylated cluster species (Fig. 2b) and confirms the composition of $\mathbf{1 a}$. The isotope distribution of the mass peaks comprises a unit of 21 silicon atoms in accordance with the presence of three $\mathrm{Si}(\mathrm{TMS})_{3}$ substituents at the $\mathrm{Si}_{9}$ cluster. In analogy, the ESI-MS spectrum of the reaction product with $\mathrm{SnCy}_{3} \mathrm{Cl}$ shows the mass peak for the tri-stannylated species $\left(\mathrm{SnCy}_{3}\right)_{3} \mathrm{Si}_{9}{ }^{-}$(2a) (Fig. 2c). However, the mass peak of the di-stannylated species $\left(\mathrm{SnCy}_{3}\right)_{2} \mathrm{Si}_{9}{ }^{-}$(Fig. 2d) was also present, although with lower 

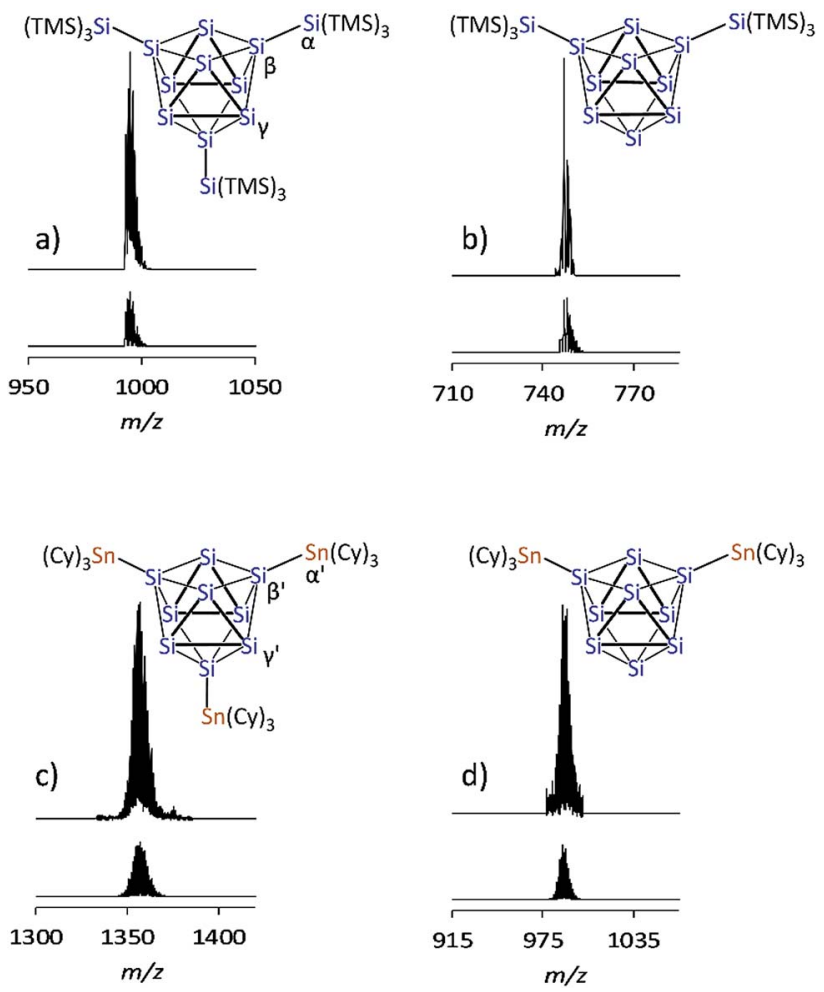

Fig. 2 ESI-MS mass peaks of the $\mathrm{Si}_{9}$ species (top: measured spectrum, bottom: simulated isotope pattern): (a) $\left.\left\{\mathrm{Si}_{(\mathrm{TMS}}\right)_{3}\right\}_{3} \mathrm{Si}_{9}(1 \mathrm{a}), \mathrm{m} / \mathrm{z}=996$; (b) $\left\{\mathrm{Si}(\mathrm{TMS})_{3}\right\}_{2} \mathrm{Si}_{9}$ from mass fragmentation (1b), $\mathrm{m} / \mathrm{z}=748$; (c) $\left(\mathrm{SnCy}_{3}\right)_{3} \mathrm{Si}_{9}(2 \mathrm{a}), \mathrm{m} / \mathrm{z}=1357$; (d) $\left(\mathrm{SnCy}_{3}\right)_{2} \mathrm{Si}_{9}(2 \mathrm{~b}), \mathrm{m} / \mathrm{z}=989$. For details of the measurement, see ESI.t.

intensity. A fragmentation mass experiment of 2 a confirmed the composition by the loss of $\mathrm{SnCy}_{3}$ in analogy to 1a and $3 \mathrm{a}^{30}$

${ }^{1} \mathrm{H}$ and ${ }^{13} \mathrm{C}$ NMR spectra of $1 \mathrm{a}$ (NMR spectra in the ESI:) exclusively show one type of TMS group $\left({ }^{1} \mathrm{H}: 0.25 \mathrm{ppm} ;{ }^{13} \mathrm{C}: 3.51\right.$ $\mathrm{ppm})$ and one set of signals for $222 \mathrm{crypt}\left({ }^{1} \mathrm{H}: 3.64,3.59\right.$, $\left.2.61 \mathrm{ppm} ;{ }^{13} \mathrm{C}: 71.47,67.44,55.01 \mathrm{ppm}\right)$. The ${ }^{1} \mathrm{H}$ NMR integral ratio of TMS : 222crypt $=3: 1$ confirms the composition of a triply silylated species for 1a (Fig. 2a). The ${ }^{1} \mathrm{H}$ and ${ }^{13} \mathrm{C}$ NMR spectra of 2a show the expected signals for the cyclohexyl groups. The Cy signals appear superimposed due to their signal splitting, but the ${ }^{13} \mathrm{C}$ NMR spectrum reveals four peaks (33.96, $31.10,25.86,21.54 \mathrm{ppm}$ ) for the $\mathrm{SnCy}_{3}$ groups of 2a. A ${ }^{119} \mathrm{Sn}$ NMR measurement reveals one single peak at $-70.50 \mathrm{ppm}$, indicative of one sort of $\mathrm{SnCy}_{3}$ groups in the reaction product, although the integral ratio $\left(\mathrm{SnCy}_{3}: 222 \mathrm{crypt}\right)$ in the ${ }^{1} \mathrm{H} \mathrm{NMR}$ measurement does not perfectly match a ratio of $3: 1$ of $2 \mathrm{a}$. Most likely, small amounts of side-products containing ( $\mathrm{K}-$ 222 crypt $)^{+}$units are responsible for this observation.

The ${ }^{29} \mathrm{Si}$ NMR spectrum of a solution of the bulk material containing 1a reveals four signals at $-8.70,-129.94,-175.29$, and $-360.72 \mathrm{ppm}$, indicative of a tri-silylated $D_{3 \mathrm{~h}}$ symmetric $\mathrm{Si}_{9}$ core. The signals at $-8.70 \mathrm{ppm}$ (TMS) and $-129.94 \mathrm{ppm}(\alpha$, Fig. 2a) originate from the attached silyl groups and conform well to reported shifts of the corresponding $\mathrm{Ge}_{9}$ species $\left\{\mathrm{Si}(\mathrm{TMS})_{3}\right\}_{3} \mathrm{Ge}_{9}{ }^{-.}{ }^{51,60}$ The signals at $-175.29(\beta$, Fig. 2a) and $-360.72 \mathrm{ppm}(\gamma$, Fig. 2a) match well with the signals reported a)

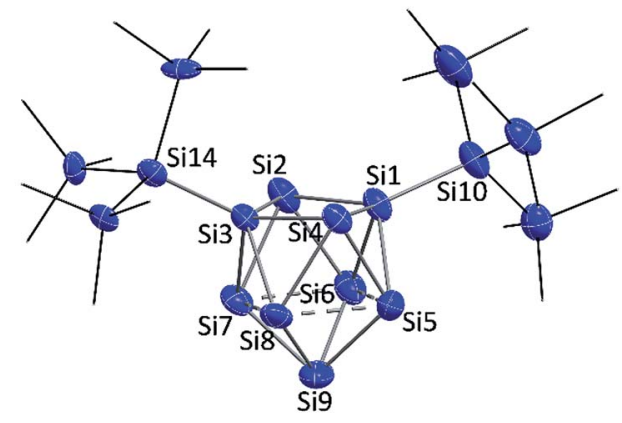

b)

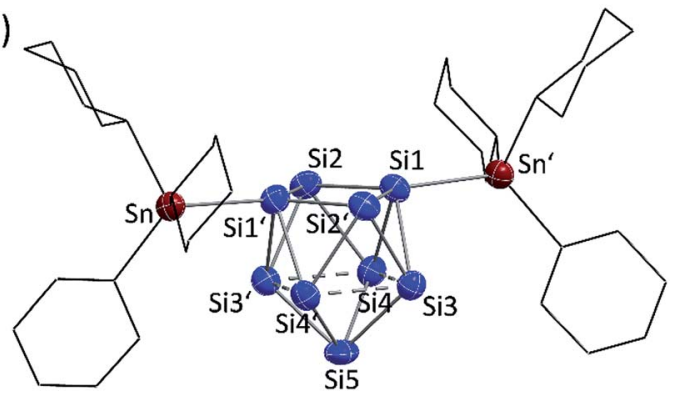

Fig. 3 Single crystal structures of di-anionic siliconoids: (a) $\left\{\mathrm{Si}(\mathrm{TMS})_{3}\right\}_{2} \mathrm{Si}_{9}{ }^{2-}$ (1b); (b) $\left(\mathrm{SnCy}_{3}\right)_{2} \mathrm{Si}_{9}{ }^{2-}$ (2b); symmetry operation: (') = $-x, y, 0.5-z$; Si and Sn atoms (blue and red-brown, respectively) are shown as ellipsoids at $50 \%$ probability level; $C$ atoms are drawn in the wire-and-stick mode; $\mathrm{H}$ atoms are omitted.

for the $\mathrm{Si}_{9}$ cluster atoms of $\left(\mathrm{SiH}^{t} \mathrm{Bu}_{2}\right)_{3} \mathrm{Si}_{9}{ }^{-}$(3a) $(-175.16$ and $-358.81 \mathrm{ppm}$, which were confirmed in computational studies) ${ }^{30}$ The ${ }^{29} \mathrm{Si}$ NMR spectrum of $2 \mathrm{a}$ reveals signals at $-100.01\left(\beta^{\prime}\right.$, Fig. $\left.2 c\right)$ and $-335.50 \mathrm{ppm}\left(\gamma^{\prime}\right.$, Fig. 2c). The signals of the substituted cluster atoms $\beta / \beta^{\prime}$ are shifted more downfield if compared to the one of the ligand-free cluster atoms of the prismatic faces $\gamma / \gamma^{\prime}$, which bear the highest negative ppm values for known siliconoids. ${ }^{19}$ The shift range of $\gamma / \gamma^{\prime}$ is comparable to that of the protonated species $\mathrm{H}_{2} \mathrm{Si}_{9}{ }^{2-}{ }^{2}(-346$ $\mathrm{ppm})^{55}$ and $\mathrm{HSi}_{9}{ }^{3-}(-359 \mathrm{ppm}) .^{54}$

Yellow block-shaped crystals suitable for single crystal X-ray diffraction were obtained from fluorobenzene/hexane solutions of bulk materials 1a and 2a. However, the structure determinations show the presence of the di-anionic siliconoid species $\left\{\mathrm{Si}(\mathrm{TMS})_{3}\right\}_{2} \mathrm{Si}_{9}{ }^{2-}(\mathbf{1 b})$ and $\left(\mathrm{SnCy}_{3}\right)_{2} \mathrm{Si}_{9}{ }^{2-}(\mathbf{2 b})$. The occurrence of the di-substituted species in the single crystals is traced back to substituent cleave from the cluster cores during crystallization. Ligand scrambling has been observed before in anionic $\mathrm{Si}_{4}$ clusters. $^{28}$ However, a disproportionation according to "2 $\left\{\mathrm{Si}(\mathrm{TMS})_{3}\right\}_{3} \mathrm{Si}_{9}{ }^{-} \rightarrow\left\{\mathrm{Si}(\mathrm{TMS})_{3}\right\}_{2} \mathrm{Si}_{9}{ }^{2-}+\left\{\mathrm{Si}(\mathrm{TMS})_{3}\right\}_{4} \mathrm{Si}_{9}{ }^{\prime}$ is excluded by to calculations due to the strongly endoenergetic nature of $+92 \mathrm{~kJ} \mathrm{~mol}^{-1}$ (further information in ESI:). EDX analyses confirmed the corresponding $\mathrm{K}: \mathrm{Si}(\mathbf{1 b})$ and $\mathrm{K}: \mathrm{Si}: \mathrm{Sn}$ (2b) ratios in the single crystals. The molecular structures of the siliconoid di-anions $\mathbf{1 b}$ and $\mathbf{2} \mathbf{b}$ are shown in Fig. 3a and b, respectively. The structures can be described as di-substituted $\mathrm{Si}_{9}$ clusters with the shape of a $C_{2 \mathrm{v}}$-distorted mono-capped square anti-prism. The substituents are attached at two opposing silicon vertex atoms of the open square of the cluster. 
Beside the $\mathrm{Si}-\mathrm{Si}$ and $\mathrm{Si}-\mathrm{Sn}$ exo-bonds, the nine $\mathrm{Si}$ atoms of the central units in $\mathbf{1 b}$ and $\mathbf{2} \mathbf{b}$ display two groups of $\mathrm{Si}-\mathrm{Si}$ bond lengths, which are listed and compared to the ones in the known anion $\mathbf{3 b}$ in Table 1 (type 1 and type 2). The shorter bonds (type 1 ) in the range between 2.40 and $2.48 \AA$ are slightly longer than typical single bonds. Interestingly, the elongations are quite small considering that $\mathrm{Si1} / \mathrm{Si3}$ in $\mathbf{1 a}$ and $\mathrm{Si1} / \mathrm{Si}^{\prime}$ in $\mathbf{2 b}$ show a coordination number of 5 . A comparison to the bond lengths within the non-capped square in the cluster $\mathrm{HSi}_{9}{ }^{3-}$ shows a significant influence of the hydrogen substituent on the $\mathrm{Si}-\mathrm{Si}$ distances. The bonds within the square with the substituted Si atom (coordination number 5) of $2.34 \AA$ are clearly shorter if compared to the ones between the unsubstituted atoms (2.55 $).{ }^{45,54}$ By contrast, the atoms Si9 (1a) and

Table 1 Selected interatomic distances $[\AA]$ in the molecular structures of the siliconoid anions $1 b, 2 b$ and $3 b$ from single crystal structure determinations (molecular structures with atom labelling in Fig. 3 and 4)

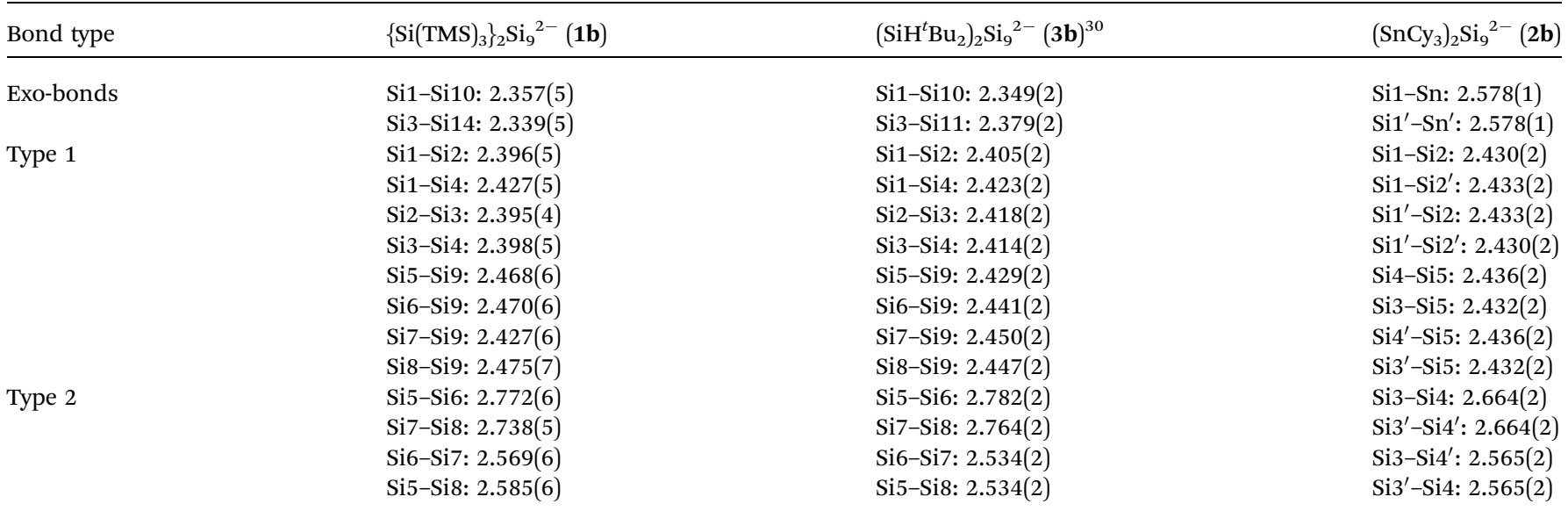

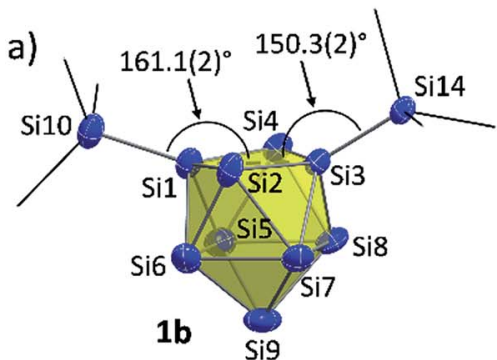

d)

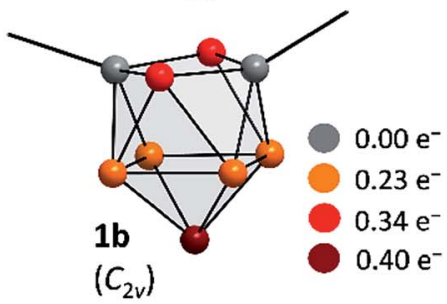

g)

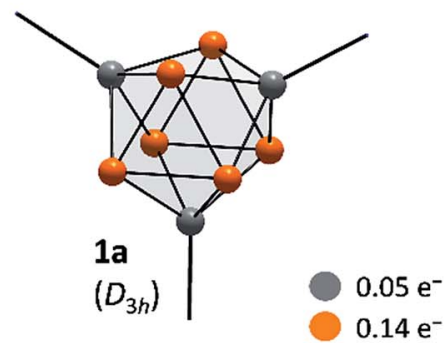

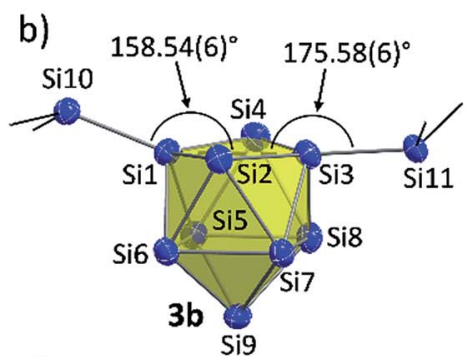

e)

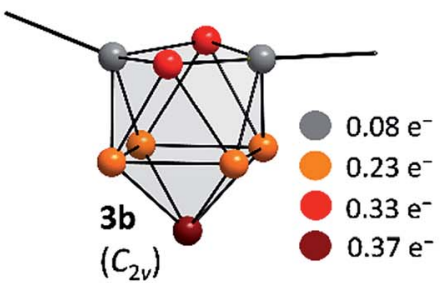

h)

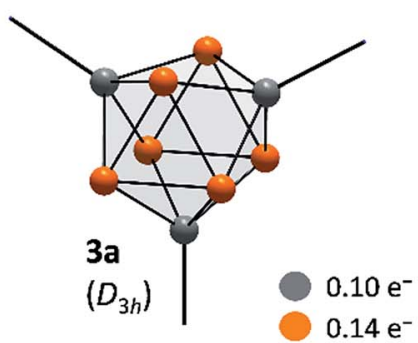

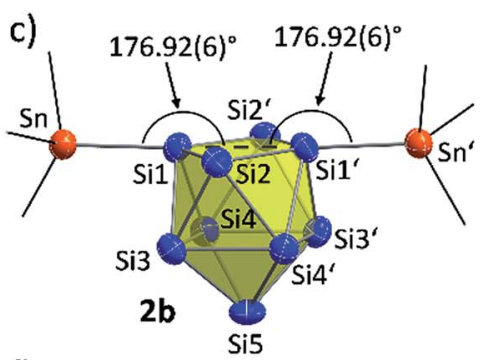

f)

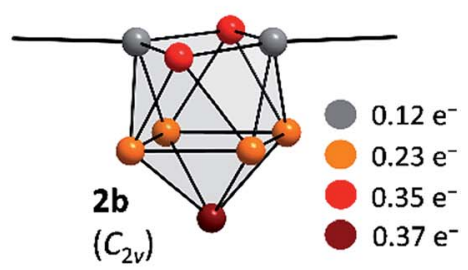

i)

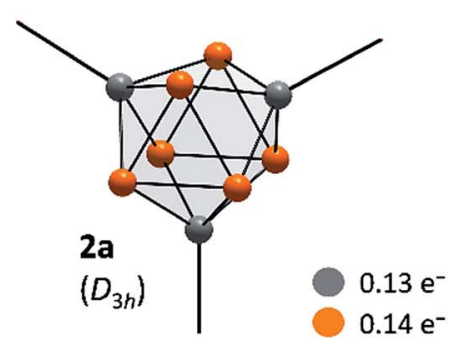

Fig. 4 Molecular structures: (a) $\left\{\mathrm{Si}(\mathrm{TMS})_{3}\right\}_{2} \mathrm{Si}_{9}{ }^{2-}$ (1b); (b) $\left(\mathrm{SiH}^{\mathrm{t}} \mathrm{Bu}_{2}\right)_{2} \mathrm{Si}_{9}{ }^{2-}$ (3b); ${ }^{30}$ (c) $\left(\mathrm{SnCy}_{3}\right)_{2} \mathrm{Si}_{9}{ }^{2-}(2 \mathrm{~b}$, symmetry operation: (') $=-x, y, 0.5-z)$;

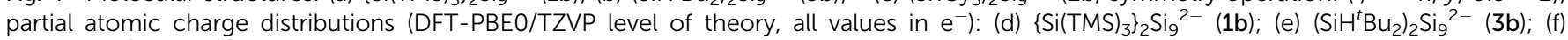
$\left(\mathrm{SnCy}_{3}\right)_{2} \mathrm{Si}_{9}{ }^{2-}(2 \mathrm{~b}) ;(\mathrm{g})\left\{\mathrm{Si}(\mathrm{TMS})_{3}\right\}_{3} \mathrm{Si}_{9}{ }^{-}(1 \mathrm{a})$; (h) $\left(\mathrm{SiH}^{t} \mathrm{Bu}_{2}\right)_{3} \mathrm{Si}_{9}{ }^{-}$(3a); (i) $\left(\mathrm{SnCy}_{3}\right)_{3} \mathrm{Si}_{9}{ }^{-}$(2a). Molecular structures: Si atoms in blue and $\mathrm{Sn}$ atoms in redbrown are shown as ellipsoids at $50 \%$ probability level; organic groups are shown as black sticks; $\mathrm{H}_{\mathrm{Si}}$ atoms in $3 \mathrm{~b}$ are omitted. 
Si5 (2b) with coordination number 4 form an umbrella-type coordination to the neighboring Si atoms. Most intriguingly, the atoms $\mathrm{Si} 5$ to $\mathrm{Si} 8$ in $\mathbf{1 b}$ and $\mathrm{Si} 3$ to $\mathrm{Si} 4$ in $\mathbf{2 b}$ each show, beside three shorter contacts of type 1 , two longer contacts to atoms of the same kind (type 2). The corresponding $\mathrm{Si}-\mathrm{Si}$ distances between 2.569(6)-2.738(5) $\AA$ in 1b and 2.565(2)-2.664(2) $\AA$ in $2 \mathbf{b}$ are in the typical region of unsubstituted $\mathrm{Si}$ atoms with an umbrella-type coordination sphere. Distances between such silicon atoms in known siliconoids as e.g. (Tip) ${ }_{5} \mathrm{Si}_{6}{ }^{-}$(2.5506(9) $\AA$, Fig. 1b), ${ }^{18}$ (Tip) ${ }_{6} \mathrm{Si}_{6}(2.7076(8) \AA)^{22}$ and (Mes) ${ }_{6} \mathrm{Si}_{5}(2.636(1) \AA)^{64}$ are comparable to the type 2 bonds.

A comparison of the molecular structures of the siliconoid di-anions $\mathbf{1 b}$, $\mathbf{2 b}$ and $\mathbf{3 b}$ (Fig. 3 and 4) shows specific differences for the arrangement of the two substituents at the respective $\mathrm{Si}_{9}$ cluster core. As expected, the longest $\mathrm{Si}_{9}$ cluster exo-bonds are detected for the stannyl derivative $3 \mathbf{b}$ with $\mathrm{Si}_{9}-\mathrm{Sn}$ bond lengths of 2.578(1) $\AA$, while the $\mathrm{Si}_{9}$-Si cluster exo-bonds in $\mathbf{1 b}$ and $\mathbf{2 b}$ are significantly shorter with values of $2.357(5) / 2.339(5) \AA(1 \mathbf{b})$ and 2.349(2)/2.379(2) A (3b) (Table 1). Si-Sn bonds in low-valent Sicompounds are scarce, but the $\mathrm{Si}_{9}-\mathrm{Sn}$ bond lengths in $\mathbf{2 b}$ compare well to the reported $\mathrm{Si}-\mathrm{Sn}$ distance in the disilene (Tip) ${ }_{3}\left(\mathrm{SnMe}_{3}\right) \mathrm{Si}_{2}(2.5675(6) \AA) .{ }^{65}$ The anion $2 \mathrm{~b}$ is located on a twofold symmetry axis, and the two equivalent Sn-Si1-Si1' and $\mathrm{Si1}-\mathrm{Si1}^{\prime}-\mathrm{Sn}^{\prime}$ angles are $176.92(6)^{\circ}$. In $2 \mathbf{b}$, the $\mathrm{Sn}$ atoms of the $\mathrm{SnCy}_{3}$ ligands are almost in plane with the non-capped cluster square formed by the atoms $\mathrm{Si} 1 / \mathrm{Si}^{\prime} / \mathrm{Si} 2 / \mathrm{Si} 2$. In the silyl derivatives $\mathbf{1 b}$ and $\mathbf{3} \mathbf{b}$, the corresponding angles are smaller, and the exo-bonds are oriented towards the open face of the clusters [1b: Si10-Si1-Si3 with $161.1(2)^{\circ}$, Si1-Si3-Si14 with $150.3(2)^{\circ}$; 3b: Si10-Si1-Si3 with $158.54(6)^{\circ}$, Si1-Si3-Si11 with $\left.175.58(6)^{\circ}\right]$. The arrangement of the stannyl substituents in 2b is consistent with the corresponding angles in the disubstituted $\mathrm{Ge}_{9}$ derivative $\left(\mathrm{SnPh}_{3}\right)_{2} \mathrm{Ge}_{9}{ }^{2-}$ [corresponding angles: $171.49(5)^{\circ}$ and $\left.172.22(5)^{\circ}\right]$ in which one exo-bond is orientated towards the capped face of the cluster. ${ }^{66}$

This indicates a certain degree of interaction of the tin atoms with next-nearest neighbor silicon cluster atoms in $\mathbf{2 b}$ as it was also indicated in the NMR experiments for the tin substituents in the disilene (Tip) $)_{3}\left(\mathrm{Sn}^{t} \mathrm{Bu}_{2} \mathrm{Cl}\right) \mathrm{Si}_{2} \cdot{ }^{65}$ Such an interaction is further supported by the formation of $\left(\mathrm{SnPh}_{3}\right) \mathrm{Ge}_{9}{ }^{3-}$ in which the stannyl ligand is bonded to two $\mathrm{Ge}_{9}$ cluster atoms. ${ }^{66}$

The highly dispersed ${ }^{29} \mathrm{Si}$ NMR signals in solution in a range from -8.70 to $-360.72 \mathrm{ppm}$ for $1 \mathrm{a}$ and from -100.01 to $-335.50 \mathrm{ppm}$ for $\mathbf{2 a}$ hint for an inhomogeneous electron distribution due to the different oxidation numbers. Such a broad range was observed before in (Tip) ${ }_{6} \mathrm{Si}_{6}$ (Tip $=2,4,6$-triisopropylphenyl) with a tricyclic structure featuring silicon atoms with two, one, and no substituents outside the ring framework. Consequently, (Tip) ${ }_{6} \mathrm{Si}_{6}$ can be regarded as a tricyclic aromatic isomer of hexasilabenzene. ${ }^{15}$ In contrast to (Tip) ${ }_{6} \mathrm{Si}_{6}$ with two $\mathrm{Si}$ atoms not attached to Tip substituents, bare $\mathrm{Si}_{9}{ }^{4-}$ clusters reveal nine such atoms. $\mathrm{Si}_{9}{ }^{4-}$ possesses a fully delocalized electronic system which fits the superatom model of a 40-electron cluster. ${ }^{6-70}$ Ligand attachment to $\mathrm{Si}_{9}{ }^{4-}$ allows for a step-wise transition to molecules with partially delocalized bonds.

In order to investigate the bond properties of the di- and trisubstituted $\mathrm{Si}_{9}$ atom clusters we calculated the partial atomic charges $\left[\mathrm{e}^{-}\right]$of the silicon cluster atoms of $\mathbf{1 a} / \mathbf{1} \mathbf{b}, \mathbf{2} \mathbf{a} / \mathbf{2} \mathbf{b}$ and $\mathbf{3 a} /$ 3b (Fig. 4). ${ }^{30}$ Comparison of the overall charge distributions shows that lower partial charges are located at substituted silicon atoms including substituent-specific charge differences underlining the electronic influence of the respective substituent on the cluster atoms (partial charges: $\mathrm{SnCy}_{3}>\mathrm{SiH}^{t} \mathrm{Bu}_{2}>$ $\left.\mathrm{Si}(\mathrm{TMS})_{3}\right)$. Interestingly, the partial charges at the unsubstituted Si atoms (prism faces) in the tri-substituted species 1a/2a/3a are all identical with a value of $0.14 \mathrm{e}^{-}$and show a homogeneous distribution of the extra negative charge at the cluster prism faces of the $D_{3 \mathrm{~h}}$ symmetric cluster. By contrast, the two extra

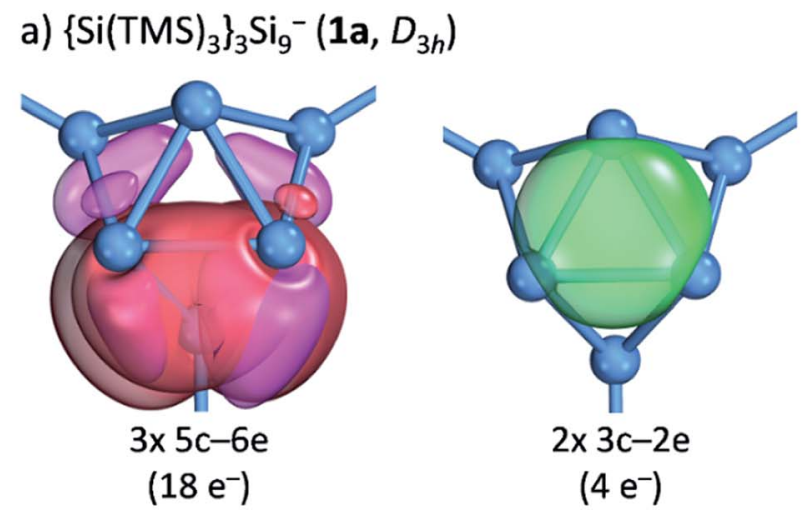

b) $\left\{\mathrm{Si}(\mathrm{TMS})_{3}\right\}_{2} \mathrm{Si}_{9}{ }^{2-}\left(\mathbf{1 b}, C_{2 v}\right)$
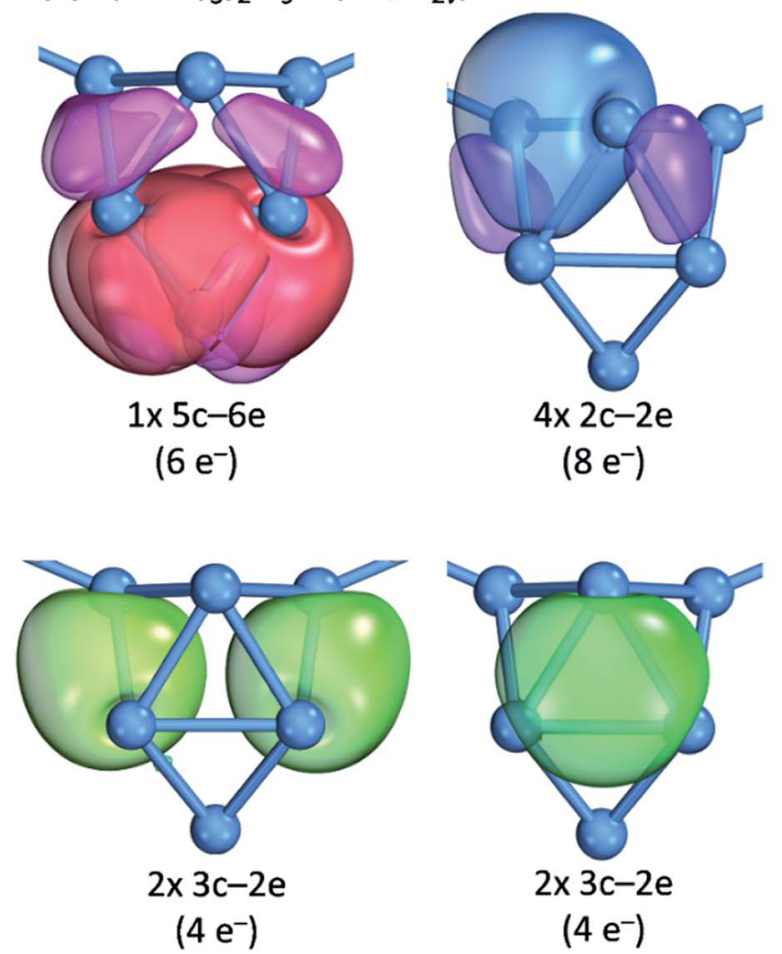

Fig. 5 Intrinsic bond orbital (IBO) analysis: (a) the $D_{3 \mathrm{~h}}$ symmetric cluster in $\left\{\mathrm{Si}(\mathrm{TMS})_{3}\right\}_{2} \mathrm{Si}_{9}{ }^{2-}$ (1a); (b) the $\mathrm{C}_{2 v}$ symmetric cluster in $\left\{\mathrm{Si}(\mathrm{TMS})_{3}\right\}_{2} \mathrm{Si}_{9}{ }^{2-}(1 \mathrm{~b})$. The plotted IBO isosurfaces enclose $80 \%$ of the total electron density of the IBO (DFT-PBEO/def2-TZVP level of theory). Details to cluster atom distributions to the respective bonds as well as to the $5 c-6 e$ bond in $1 \mathrm{~b}$ are shown in the ESI.t. 
negative charges in the di-substituted $C_{2 \mathrm{v}}$ symmetric clusters $\mathbf{1} \mathbf{b}$, $\mathbf{2 b}$ and $\mathbf{3 b}$ are distributed more versatilely on the cluster surfaces consisting of ligand-free $\mathrm{Si}$ atoms. The partial atomic charges of the silicon atoms in the capped cluster squares $[\mathbf{1 b} / \mathbf{3 b}$ : $\mathrm{Si} 5$ to Si8; 2b: $\mathrm{Si3}\left({ }^{\prime}\right)$ and $\mathrm{Si} 4\left(^{\prime}\right)$ ] are equal for all species with a value of $0.23 \mathrm{e}^{-}$ for each atom, whereas the highest partial charges at the squarecapping silicon atoms, from which the substituents are detached during crystallization, is found in $\mathbf{1 b}\left(0.40 \mathrm{e}^{-}, \mathrm{Si} 9\right.$ atom $)$.

Further insight into the bonding situation within the cluster units is provided by an IBO analysis of $\mathbf{1 a}$ and $\mathbf{1 b}$ (Fig. 5) that manifests an influence of the third substituent on the bonding situation within the $\mathrm{Si}_{9}$ cluster cores. The analysis shows a delocalization of the cluster valence electrons (total: $40 \mathrm{e}^{-}$) that is in accordance with a previous report for related trissubstituted nona-germanium clusters $^{71}$ stronger for $D_{3 \mathrm{~h}}$ symmetric 1a than for $C_{2 \mathrm{v}}$ symmetric 1b. Delocalization in 1a occurs by three $5 \mathrm{c}-6 \mathrm{e}$ ( 5 center- 6 electron) bonds $\left(18 \mathrm{e}^{-}\right)$within the three capped square faces and by two $3 \mathrm{c}-2 \mathrm{e}$ bonds $\left(4 \mathrm{e}^{-}\right)$in the two prism faces. A comparison to the bonding situation in 1b shows that only one delocalized $5 \mathrm{c}-6 \mathrm{e}$ bond $\left(6 \mathrm{e}^{-}\right)$is present here which is located within the capped square of the cluster from which cap the substituent is released. Most interestingly, causes the attachment of two ligands a high degree of bond localization in form of four covalent $2 \mathrm{c}-2 \mathrm{e}$ bonds $\left(8 \mathrm{e}^{-}\right)$in $\mathbf{1 b}$ in the non-capped square of the cluster. Furthermore, two $3 \mathrm{c}-2 \mathrm{e}$ bonds (total $8 \mathrm{e}^{-}$) are present in the triangular faces of $\mathbf{1 b}$. The remaining 18 cluster valence electrons of $\mathbf{1 a}$ and $\mathbf{1 b}$ are located in the covalent cluster exo-bonds $\left(1 \mathbf{a}: 6 \mathrm{e}^{-} ; \mathbf{1 b}: 4 \mathrm{e}^{-}\right)$and in six lone pairs which are distributed over the naked Si cluster atoms (1a: $12 \mathrm{e}^{-}$, six lone pairs: 1b: $14 \mathrm{e}^{-}$, seven lone pairs). Similar bond delocalization was also reported for hexasilabenzene ${ }^{15}$ in which theoretical analysis revealed the cyclic delocalization of six mobile electrons of the p-, s- and non-bonding type across the central four-membered ring and which was described as dismutational aromatic. The herein presented study to the charge distributions within substituted $\mathrm{Si}_{9}$ clusters adds these cluster species as delocalized species to the known silicon molecules in the literature.

Furthermore, the crystals were characterized by Raman spectroscopy, and the measured vibrations are assigned by comparison to calculated Raman spectra of $\mathbf{1 b}$ and $\mathbf{2 b}$ (Fig. 6). Changes of intensities might be due to specific packing effects (calculations were performed on discrete anionic species) and to orientation effects of the single crystal. In both cases characteristic $\tilde{v}(\mathrm{Si}-\mathrm{Si})$ stretching vibrations of the $\mathrm{Si}_{9}$ cluster cores were detected which agree well with the calculated values.
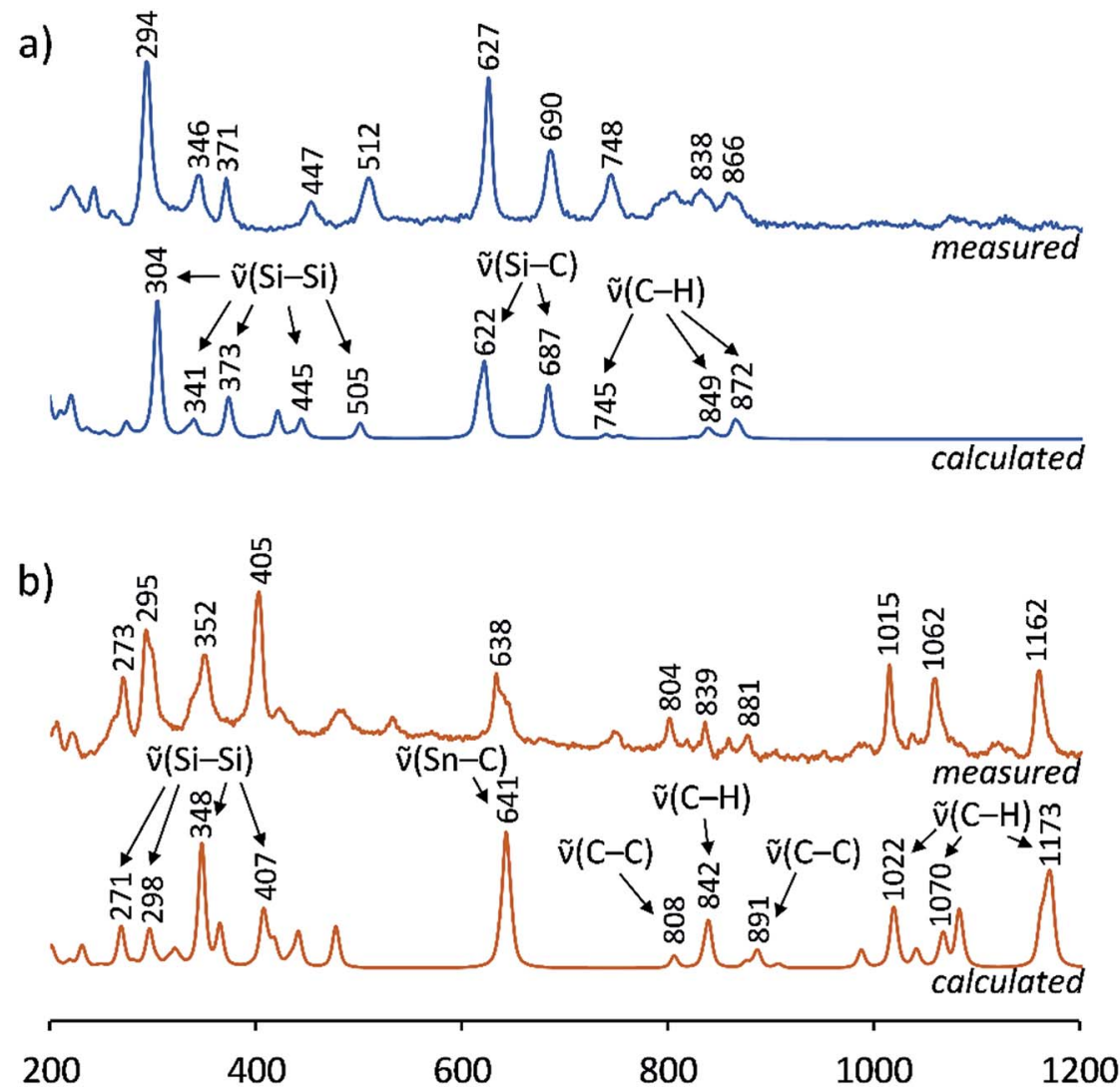

Ramanshift $\left[\mathrm{cm}^{-1}\right]$

Fig. 6 Raman spectra of single crystals: (a) measured spectrum of a (K-222crypt) ${ }_{2} 1 \mathrm{~b}$ single crystal (blue, top), calculated spectrum of $\left\{\mathrm{Si}(\mathrm{TMS})_{3}\right\}_{2} \mathrm{Si}_{9}{ }^{2-}$ (1b) by DFT-PBE0/TZVP (blue, bottom); (b) measured spectrum of a (K-222crypt) 2 b single crystal (red-brown, top), calculated spectrum of $\left(\mathrm{SnCy}_{3}\right)_{2} \mathrm{Si}_{9}{ }^{2-}$ (2b) by DFT-PBEO/TZVP (red-brown, bottom); details of the calculations can be found in the ESI.t. 
Interestingly, the peaks and the distribution range of the cluster vibrations are different for the two siliconoids (1b: 294, 346, $371,447 \mathrm{~cm}^{-1}$; 2b: 273, 295, 352, $405 \mathrm{~cm}^{-1}$ ), which indicates an influence of the respective substituent on the $\mathrm{Si}_{9}$ intra-bonds. All vibrations for the stannyl derivative 2b (range: 273$405 \mathrm{~cm}^{-1}$ ) are found at lower wavenumbers than those of $\mathbf{1 b}$ (range: $294-512 \mathrm{~cm}^{-1}$ ). For $\mathbf{1 b}$, an $\mathrm{Si}_{9}-\mathrm{Si}(\mathrm{TMS})_{3}$ vibration for the cluster exo-bond was found at $512 \mathrm{~cm}^{-1}$, whereas the $\mathrm{Si}_{9}-\mathrm{SnCy}_{3}$ exo-bonds are not detectable due to laser absorption effects in the spectrum below $200 \mathrm{~cm}^{-1}$. Moreover, $\tilde{v}[\mathrm{Si}-\mathrm{C}]$ and $\tilde{v}[\mathrm{C}-\mathrm{H}]$ vibrations were observed for $\mathbf{1 b}$ and $\tilde{v}[\mathrm{Sn}-\mathrm{C}], \tilde{v}[\mathrm{C}-\mathrm{C}]$ and $\tilde{v}[\mathrm{C}-\mathrm{H}]$ vibrations for $\mathbf{2 b}$, which also include the vibrations for the (K222crypt) units in the single crystals.

Up to this study, the Raman spectra of $\mathrm{Si}_{9}$ cluster compounds comprised the protonated cluster species $\mathrm{H}_{2} \mathrm{Si}_{9}{ }^{2-}$ and $\mathrm{Si}_{9}{ }^{4-}$ that show less Raman vibrations. The spectrum of $\mathrm{H}_{2} \mathrm{Si}_{9}{ }^{2-}$ displays a prominent resonance at $386 \mathrm{~cm}^{-1}$ and a resonance of $\mathrm{Si}_{9}{ }^{4-}$ as part of the solid phase $\mathrm{K}_{12} \mathrm{Si}_{17}$ at $390 \mathrm{~cm}^{-1} .^{55}$ In contrast, multiple $\mathrm{Si}_{9}$ vibrations are confirmed for the ligand-stabilized clusters $\mathbf{1 b}$ / $\mathbf{2 b}$, and a possible correlation with the delocalized bonding situation from the IBO analysis is of interest for future reports.

\section{Conclusions}

The synthetic approach for silicon-rich molecules comprising silicon atoms with low oxidation state from the binary intermetallic precursor $\mathrm{K}_{12} \mathrm{Si}_{17}$ is established. For the first time a metal atom is attached to a $\mathrm{Si}_{9}$ cluster core pathway allowing for the structural characterization of $\mathrm{Cy}_{3} \mathrm{Sn}-\left(\mathrm{Si}_{9}{ }^{2-}\right)-\mathrm{SnCy}_{3}(2 \mathbf{b})$. In addition the anionic siliconoid $\left\{\mathrm{Si}(\mathrm{TMS})_{3}\right\}_{2} \mathrm{Si}_{9}{ }^{2-}(\mathbf{1 b})$ is structurally characterized. Both anions form via the tris-substituted derivatives $\left(\mathrm{SnCy}_{3}\right)_{3} \mathrm{Si}_{9}{ }^{-}(\mathbf{1 a})$ and $\left\{\mathrm{Si}(\mathrm{TMS})_{3}\right\}_{3} \mathrm{Si}_{9}{ }^{-}$(2a) that have been spectroscopically characterized. In contrast to known "molecular multi-step" approaches, the syntheses became feasible via a twostep reaction from elemental silicon. The molecular anions possess high numbers of unsubstituted Si cluster atoms and add as novel delocalized representatives to known silicon compounds in the literature. Moreover, the influence of the ligands on bond localization at the $\mathrm{Si}_{9}$ cluster cores was pointed out.

\section{Experimental section}

General

All reactions and manipulations were performed under a purified argon atmosphere using standard Schlenk and glove box techniques. Thf was dried using the solvent purificator MBraun MB-SPS, and fluorobenzene was dried over $\mathrm{CaH}_{2}$ prior to use. 222crypt was dried in vacuo prior to use. Liquid ammonia was dried and stored over sodium metal, and all other solvents (including deuterated solvents) were stored over molecular sieves $(3 \AA)$. All other chemicals were received commercially and used without further purification.

\section{$\mathrm{K}_{12} \mathrm{Si}_{17}$ (activated)}

The Zintl compound $\mathrm{K}_{12} \mathrm{Si}_{17}$ was synthesized by heating (heating rate: $2{ }^{\circ} \mathrm{C} \min ^{-1}$ ) a stoichiometric mixture of $0.55 \mathrm{~g} \mathrm{~K}$
(14.0 mmol, 1 eq.) and $0.59 \mathrm{~g} \mathrm{Si} \mathrm{(21.1} \mathrm{mmol,} 1.5$ eq.) in a sealed tantalum ampoule to $800{ }^{\circ} \mathrm{C}$ for $15 \mathrm{~h}$ and subsequent cooling (cooling rate: $0.5{ }^{\circ} \mathrm{C} \mathrm{min}^{-1}$ ) to room temperature. The ampoule was opened in a glove box, and the product was finely ground yielding $1.04 \mathrm{~g} \mathrm{~K}_{12} \mathrm{Si}_{17}(1.10 \mathrm{mmol}$, 94\%) as a black solid. The solid was characterized by powder X-ray diffraction showing high purity for the solid phase (ESI ). For the activation, $0.20 \mathrm{~g}$ $\mathrm{K}_{12} \mathrm{Si}_{17}$ (0.21 mmol, 1 eq.) and $0.15 \mathrm{~g} 222$ crypt (0.39 mmol, 1.9 eq.; 4,7,13,16,21,24-hexaoxa-1,10-diazabicyclo[8.8.8]hexacosan) were weighed into a Schlenk tube, and liquid ammonia was added at $-78{ }^{\circ} \mathrm{C}\left(\mathrm{iPrOH} / \mathrm{CO}_{2}\right)$ to give a dark red solution. The solution was stirred at $-78{ }^{\circ} \mathrm{C}$ for $2 \mathrm{~h}$, and $\mathrm{K}_{12} \mathrm{Si}_{17}$ (activated) was obtained as a brown solid after the removal of liquid ammonia.

\section{$(\mathrm{K}-222 \mathrm{crypt})^{+}$salts of $1 \mathrm{a}$ and $1 \mathrm{~b}$}

$\mathrm{K}_{12} \mathrm{Si}_{17}$ activated (batch with $200 \mathrm{mg} \mathrm{K}_{12} \mathrm{Si}_{17}$ ) was cooled to $0{ }^{\circ} \mathrm{C}$ (ice bath), and thf $(12 \mathrm{~mL})$ was added. $0.36 \mathrm{~g} \mathrm{Si}(\mathrm{TMS})_{3} \mathrm{Cl}$ (1.26 mmol, 6 eq.) was added under continuous stirring as a pre-cooled thf solution $(3 \mathrm{~mL})$. The reaction mixture was stirred overnight and allowed to warm to room temperature. A brownish filtrate was obtained after filtration, and all volatiles were removed in vacuo. The residue was extracted with fluorobenzene $(5 \mathrm{~mL})$, and a red filtrate was obtained. After washing with hexane and vacuum drying, a light brown solid containing the $(\mathrm{K}-222 \mathrm{crypt})^{+}$salt of $\mathbf{1 a}$ was obtained (yield: $0.12 \mathrm{~g}, 40 \%$ based on $\mathrm{K}_{12} \mathrm{Si}_{17}$ ). The solid was characterized by ESI-MS in thf and NMR spectroscopy $\left({ }^{1} \mathrm{H},{ }^{13} \mathrm{C},{ }^{29} \mathrm{Si}\right)$ in solution (thf- $\left.d_{8}\right)$. For crystallization, a fluorobenzene solution of the solid $(3 \mathrm{~mL})$ was layered with hexane. Yellow block-shaped crystals of the $(\mathrm{K}-222 \mathrm{crypt})^{+}$salt of $\mathbf{1 b}$ suitable for single crystal X-ray diffraction were obtained after $10 \mathrm{~d}(10 \mathrm{mg}, 10 \%$ based on (K-222crypt)1a). The crystals were investigated by Raman spectroscopy, and the $\mathrm{K}$ : Si ratio was confirmed by EDX analyses on single crystals.

Bulk material containing 1a. ESI-MS (negative mode, $4500 \mathrm{~V}$, $\left.300{ }^{\circ} \mathrm{C}\right): m / z=996\left\{\mathrm{Si}(\mathrm{TMS})_{3}\right\}_{3} \mathrm{Si}_{9}{ }^{-} ;{ }^{1} \mathrm{H}$ NMR $\left(500 \mathrm{MHz}\right.$, thf- $\left.d_{8}\right)$ $\delta 3.64\left(\mathrm{~s}, 12 \mathrm{H}, \mathrm{O}-\mathrm{CH}_{2}-\mathrm{CH}_{2}-\mathrm{O}_{222 \text { crypt }}\right), 3.59(\mathrm{t}, J=5.05 \mathrm{~Hz}, 12 \mathrm{H}$, $\left.\mathrm{O}-\mathrm{CH}_{2}-\mathrm{CH}_{2}-\mathrm{N}_{222 \text { crypt }}\right), 2.61\left(\mathrm{t}, 12 \mathrm{H}, \mathrm{J}=5.10 \mathrm{~Hz}, \mathrm{O}-\mathrm{CH}_{2}-\mathrm{CH}_{2}-\right.$ $\mathrm{N}_{22 \text { crypt }}$ ), 0.25 (s, 81H, SiMe 3 ); ${ }^{13} \mathrm{C}\left\{{ }^{1} \mathrm{H}\right\}$ NMR (75 MHz, thf- $d_{8}$ ) $\delta 71.47\left(\mathrm{O}-\mathrm{CH}_{2}-\mathrm{CH}_{2}-\mathrm{O}_{222 \text { crypt }}\right), 67.44\left(\mathrm{O}-\mathrm{CH}_{2}-\mathrm{CH}_{2}-\mathrm{N}_{222 \text { crypt }}\right)$, $55.01\left(\mathrm{O}-\mathrm{CH}_{2}-\mathrm{CH}_{2}-\mathrm{N}_{222 \text { crypt }}\right), 3.51\left(\mathrm{SiMe}_{3}\right) ;{ }^{29} \mathrm{Si}\left\{{ }^{1} \mathrm{H}\right\}$ NMR (99 $\mathrm{MHz}$, thf- $\left.d_{8}\right) \delta-8.70\left[\mathrm{Si}(\mathrm{TMS})_{3}\right],-129.94\left[\mathrm{Si}(\mathrm{TMS})_{3}\right],-175.29$ $\left[\mathrm{Si}-\mathrm{Si}(\mathrm{TMS})_{3}\right],-360.72\left[\mathrm{Si}-\mathrm{Si}-\mathrm{Si}(\mathrm{TMS})_{3}\right]$.

Single crystals containing 1b. EDX analysis [single crystals of (K-222crypt) ${ }_{2} \mathbf{1 b}$ ]: $\mathrm{K}: \mathrm{Si}=6.30 \%$ : 93.7\% (calcd: $6.22 \%: 93.8 \%$ ); Raman (532 nm): 294 [ $\tilde{v}(\mathrm{Si}-\mathrm{Si})$ calcd 304], $346[\tilde{v}(\mathrm{Si}-\mathrm{Si})$ calcd 341], 371 [ $\tilde{v}(\mathrm{Si}-\mathrm{Si})$ calcd 373], 447 [ $\tilde{v}(\mathrm{Si}-\mathrm{Si})$ calcd 445], 512 [ $\tilde{v}(\mathrm{Si}-$ $\mathrm{Si})$ calcd 505], 627 [ $\tilde{v}(\mathrm{Si}-\mathrm{C})$ calcd 622], 690 [v(Si-C) calcd 687], $748[\tilde{v}(\mathrm{C}-\mathrm{H})$ calcd 745], $838[\tilde{v}(\mathrm{C}-\mathrm{H})$ 849], $866[\tilde{v}(\mathrm{C}-\mathrm{H})$ calcd $872] \mathrm{cm}^{-1}$.

\section{$(\mathrm{K}-222 \mathrm{crypt})^{+}$salts of $2 \mathrm{a}$ and $2 \mathrm{~b}$}

$\mathrm{K}_{12} \mathrm{Si}_{17}$ activated (batch with $200 \mathrm{mg} \mathrm{K}_{12} \mathrm{Si}_{17}$ ) was cooled to $0{ }^{\circ} \mathrm{C}$ (ice bath), and pyridine $(12 \mathrm{~mL})$ was added. $0.51 \mathrm{~g}$ (1.26 mol, 6 eq.) $\mathrm{SnCy}_{3} \mathrm{Cl}$ was added under continuous stirring as pre-cooled pyridine solution $(3 \mathrm{~mL})$. The reaction mixture was stirred 
overnight and filtered under continuous cooling yielding a colored filtrate which was dried in vacuo and extracted with fluorobenzene $(5 \mathrm{~mL})$. The red filtrate was dried in vacuo, and a brown solid containing the (K-222crypt) ${ }^{+}$salt of 2 a was obtained (yield: $0.10 \mathrm{~g}, 27 \%$ based on $\mathrm{K}_{12} \mathrm{Si}_{17}$ ). The solid was investigated by ESI-MS in thf and NMR spectroscopy $\left({ }^{1} \mathrm{H},{ }^{13} \mathrm{C}\right.$, ${ }^{29} \mathrm{Si},{ }^{119} \mathrm{Sn}$ ) in solution (thf- $d_{8}$ ). For crystallization, a fluorobenzene solution of the solid $(3 \mathrm{~mL})$ was layered with hexane. Yellow block-shaped crystals of the (K-222crypt) ${ }^{+}$salt of $\mathbf{2 b}$ suitable for single crystal X-ray diffraction were obtained after $12 \mathrm{~d}$ (7 mg, 7\% based on (K-222crypt)2a). The crystals were investigated by Raman spectroscopy, and the $\mathrm{K}$ : Si ratio was confirmed by EDX analyses on single crystals.

Bulk material containing 2a. ESI-MS (negative mode, $4500 \mathrm{~V}$, $\left.300{ }^{\circ} \mathrm{C}\right): m / z=1357\left(\mathrm{SnCy}_{3}\right)_{3} \mathrm{Si}_{9}{ }^{-}, m / z=996\left(\mathrm{SnCy}_{3}\right)_{2} \mathrm{Si}_{9}{ }^{-} ;{ }^{1} \mathrm{H}$ NMR (400 MHz, thf- $\left.d_{8}\right) \delta 3.67$ (s, $12 \mathrm{H}, \mathrm{O}-\mathrm{CH}_{2}-\mathrm{CH}_{2}-\mathrm{O}_{222 \text { crypt }}$ ), 3.61 (s, $\left.12 \mathrm{H}, \mathrm{O}-\mathrm{CH}_{2}-\mathrm{CH}_{2}-\mathrm{N}_{222 \text { crypt }}\right), 2.61$ (s, $12 \mathrm{H}, \mathrm{O}-\mathrm{CH}_{2}-\mathrm{CH}_{2}-$ $\mathrm{N}_{\text {222crypt }}$ ), $1.94-1.30$ (m, 69H, $\left.H_{\text {cyclohexyl }}\right) ;{ }^{13} \mathrm{C}\left\{{ }^{1} \mathrm{H}\right\}$ NMR (126 $\mathrm{MHz}$, thf- $\left.d_{8}\right) \delta 71.58\left(\mathrm{O}-\mathrm{CH}_{2}-\mathrm{CH}_{2}-\mathrm{O}_{222 \text { crypt }}\right), 68.71\left(\mathrm{O}-\mathrm{CH}_{2}-\right.$ $\left.\mathrm{CH}_{2}-\mathrm{N}_{222 \text { crypt }}\right), 55.09$ (O- $\left.\mathrm{CH}_{2}-\mathrm{CH}_{2}-\mathrm{N}_{222 \text { crypt }}\right), 33.96$ ( $\left.C_{\text {cyclohexyl }}\right)$, $31.10\left(C_{\text {cyclohexyl }}\right), 25.86\left(C_{\text {cyclohexyl }}\right), 21.54\left(C_{\text {cyclohexyl }}\right) ;{ }^{29} \mathrm{Si}\left\{{ }^{1} \mathrm{H}\right\}$ NMR (99 MHz, thf- $\left.d_{8}\right) \delta-100.01\left[S i-S n(C y)_{3}\right],-335.50[S i-S i-$ $\left.\mathrm{Sn}(\mathrm{Cy})_{3}\right] ;{ }^{119} \mathrm{Sn}\left\{{ }^{1} \mathrm{H}\right\}$ NMR $\left(112 \mathrm{MHz}\right.$, thf- $\left.d_{8}\right) \delta-70.50\left[\operatorname{Sn}(\mathrm{Cy})_{3}\right]$.

Single crystals containing $2 \mathbf{b}$. EDX analysis [single crystals of $\left.(\mathrm{K}-222 \mathrm{crypt})_{2} 2 \mathrm{~b}\right]: \mathrm{K}: \mathrm{Si}: \mathrm{Sn}=15.5 \%: 44.1 \%: 40.4 \%$ (calcd: 13.8\% : 44.5\% : 41.8\%); Raman (785 nm):, 273 [ $\tilde{v}(\mathrm{Si}-\mathrm{Si})$ calcd 271], 295 [ $\tilde{v}(\mathrm{Si}-\mathrm{Si})$ calcd 298], 352 [ $\tilde{v}(\mathrm{Si}-\mathrm{Si})$ calcd 348], 405 [ $\tilde{v}(\mathrm{Si}-$ Si) calcd 407], 638 [ $\tilde{v}(\mathrm{Sn}-\mathrm{C})$ calcd 641], 804 [ $(\mathrm{V}-\mathrm{C})$ calcd 808], $839[\tilde{v}(\mathrm{C}-\mathrm{H})$ calcd 842], 881 [ $(\mathrm{C}-\mathrm{C})$ calcd 891], $1015[\tilde{v}(\mathrm{C}-\mathrm{H})$ calcd 1022], $1062[\tilde{v}(\mathrm{C}-\mathrm{H})$ calcd 1070], $1162[\tilde{v}(\mathrm{C}-\mathrm{H})$ calcd $1173] \mathrm{cm}^{-1}$.

\section{Computational details}

Quantum-chemical calculations at the DFT-PBE0/TZVP level of theory were carried out using the TURBOMOLE program package. ${ }^{72-76}$ Intrinsic atomic orbitals (IAOs) and intrinsic bond orbitals were used to analyze the partial charges and bonding of the clusters, respectively. ${ }^{77}$ Full computational details are available in the ESI.t

\section{Single crystal structure determination}

For single crystal data collection, the crystals were fixed on a glass capillary and positioned in a cold stream of $\mathrm{N}_{2}$ gas. Single crystal data collection was performed with a STOE StadiVari (Mo $K \alpha$ radiation) diffractometer equipped with a DECTRIS PILATUS 300K detector. Structures were solved by Direct Methods (SHELXS-2014) and refined by full-matrix leastsquares calculations against $F^{2}$ (SHELXL-2014). ${ }^{78}$ The positions of the hydrogen atoms were calculated and refined using a riding model. Unless otherwise stated, all non-hydrogen atoms were treated with anisotropic displacement parameters. In $\mathbf{1 b}$ some hypersilyl groups show rotational disorder and were refined at two split positions. In $\mathbf{2} \mathbf{b}$, one cyclohexyl group is found in two different orientations and was refined at two split positions. For visualization, the crystal structures have been plotted with Diamond. t9 $^{79}$

\section{Electron dispersive X-ray (EDX) analysis}

Single crystals of all compounds were analyzed with a SWIFTED-TM (Oxford Instruments) and a Hitachi TM-1000 Tabletop microscope (Hitachi High-Technologies) with the INCA system software.

\section{NMR spectroscopy}

${ }^{1} \mathrm{H},{ }^{13} \mathrm{C}$ and ${ }^{29} \mathrm{Si}$ NMR spectra were recorded on a Bruker AVIII Ultrashield $400 \mathrm{MHz}$ or a Bruker AVIII $500 \mathrm{MHz}$ Cryo system, ${ }^{119} \mathrm{Sn}$ NMR spectra were measured on a Bruker AVIII $300 \mathrm{MHz}$ (Bruker Inc) instrument. The signals of the ${ }^{1} \mathrm{H}$ and ${ }^{13} \mathrm{C}$ spectra were calibrated on the rest proton signal of the used deuterated solvent thf- $d_{8}$. Chemical shift values are given in $\delta$ values by parts per million (ppm). The coupling constants $J$ are stated in Hz. Signal multiplicities are abbreviated as follows: $s$ singlet, $\mathrm{d}$ - doublet, $\mathrm{t}$ - triplet, $\mathrm{m}$ - triplet. The spectra were evaluated with MestReNova. ${ }^{80}$

\section{Electrospray ionization mass spectrometry (ESI-MS)}

The preparation of the samples was done in a glove box. The spectra were measured on an HCT instrument (Bruker Inc). The data were analyzed using the program Bruker Compass Data Analysis 4.0 SP 5. The dry gas temperature was adjusted to $300{ }^{\circ} \mathrm{C}$ and the injection speed to $240 \mu \mathrm{L} \mathrm{s}^{-1}$. For fragmentation experiments, the respective mass peaks were isolated (width: 40) and fragmented (amplitude: 2.0). Visualization of the spectra was carried out with the programs OriginPro (Origin Lab Inc) or Microsoft Excel (Microsoft Inc).

\section{Raman spectroscopy}

Raman spectra were recorded with an inVia Raman Microscope RE04 with a CCD detector and $500 \mathrm{~mW}$ maximal power (Renishaw PLC; Software: WiRE 4.2 build 5037) at $\lambda=532 \mathrm{~nm}$. For the measurements the samples were sealed in glass capillaries in a glove box.

\section{Powder X-ray diffraction (PXRD)}

The data were collected at room temperature on a STOE Stadi P diffractometer ( $\mathrm{Ge}(111)$ monochromator, $\mathrm{Cu} \mathrm{K} \alpha_{1}$ radiation, $\lambda=$ $1.54056 \AA$ ) with a Dectris MYTHEN $1 \mathrm{~K}$ detector in DebyeScherrer geometry. For the measurements the samples were sealed in glass capillaries $(\varnothing 0.5 \mathrm{~mm})$. The raw data were processed with WinX-POW, ${ }^{\mathbf{8 1}}$ OriginPro (Origin Lab Inc) was used for the visualization.

\section{Conflicts of interest}

There are no conflicts to declare.

\section{Acknowledgements}

The authors are thankful for the financial support by WACKER Chemie AG and Deutsche Forschungsgemeinschaft (DFG, FA 198/14-1). They thank Sebastian Geier and Christoph Wallach for the Raman measurements, Maria Müller for the EDX 
analyses, Brigita Bratic for supporting the syntheses and Dr Annette Schier for proofreading. A. J. K. thanks the Academy of Finland for funding (grant 308089) and the Finnish IT Center for Science (CSC) for computational resources.

\section{References}

1 M. Ashuri, Q. He and L. L. Shaw, Nanoscale, 2016, 8, 74-103.

2 M. G. Kanatzidis, Adv. Mater., 2007, 19, 1165-1181.

3 R. A. Bley and S. M. Kauzlarich, J. Am. Chem. Soc., 1996, 118, 12461-12462.

4 C. Eun-Chel, P. Sangwook, H. Xiaojing, S. Dengyuan, C. Gavin, P. Sang-Cheol and A. G. Martin, Nanotechnology, 2008, 19, 245201.

5 L. T. Canham, Appl. Phys. Lett., 1990, 57, 1046-1048.

6 J. K. Rath, B. Stannowski, P. A. T. T. van Veenendaal, M. K. van Veen and R. E. I. Schropp, Thin Solid Films, 2001, 395, 320-329.

7 M. L. Snedaker, Y. Zhang, C. S. Birkel, H. Wang, T. Day, Y. Shi, X. Ji, S. Kraemer, C. E. Mills, A. Moosazadeh, M. Moskovits, G. J. Snyder and G. D. Stucky, Chem. Mater., 2013, 25, 4867-4873.

8 L. Venema, Nature, 2011, 479, 309.

9 D. N. Roark and G. J. D. Peddle, J. Am. Chem. Soc., 1972, 94, 5837-5841.

10 R. West, M. J. Fink and J. Michl, Science, 1981, 214, 13431344.

11 A. G. Brook, F. Abdesaken, B. Gutekunst, G. Gutekunst and R. K. Kallury, Chem. Commun., 1981, 191-192.

12 A. G. Brook, S. C. Nyburg, F. Abdesaken, B. Gutekunst, G. Gutekunst, R. Krishna, M. R. Kallury, Y. C. Poon, Y. M. Chang and W. N. Winnie, J. Am. Chem. Soc., 1982, 104, 5667-5672.

13 A. Sekiguchi, R. Kinjo and M. Ichinohe, Science, 2004, 305, 1755-1757.

14 M. Denk, R. Lennon, R. Hayashi, R. West, A. V. Belyakov, H. P. Verne, A. Haaland, M. Wagner and N. Metzler, J. Am. Chem. Soc., 1994, 116, 2691-2692.

15 K. Abersfelder, A. J. P. White, H. S. Rzepa and D. Scheschkewitz, Science, 2010, 327, 564-566.

16 K. C. Mondal, S. Roy, B. Dittrich, D. M. Andrada, G. Frenking and H. W. Roesky, Angew. Chem., Int. Ed., 2016, 55, 31583161.

17 D. Scheschkewitz, Angew. Chem., Int. Ed., 2005, 44, 29542956.

18 P. Willmes, K. Leszczyńska, Y. Heider, K. Abersfelder, M. Zimmer, V. Huch and D. Scheschkewitz, Angew. Chem., Int. Ed., 2016, 55, 2907-2910.

19 Y. Heider and D. Scheschkewitz, Dalton Trans., 2018, 47, 7104-7112.

20 T. Iwamoto, N. Akasaka and S. Ishida, Nat. Commun., 2014, $5,5353$.

21 G. Fischer, V. Huch, P. Mayer, S. K. Vasisht, M. Veith and N. Wiberg, Angew. Chem., Int. Ed., 2005, 44, 7884-7887.

22 K. Abersfelder, A. J. P. White, R. J. F. Berger, H. S. Rzepa and D. Scheschkewitz, Angew. Chem., Int. Ed., 2011, 50, 79367939.
23 K. Abersfelder, A. Russell, H. S. Rzepa, A. J. P. White, P. R. Haycock and D. Scheschkewitz, J. Am. Chem. Soc., 2012, 134, 16008-16016.

24 N. Akasaka, S. Ishida and T. Iwamoto, Inorganics, 2018, 6, 107.

25 S. David, Chem. Lett., 2011, 40, 2-11.

26 Y. Ohmori, M. Ichinohe, A. Sekiguchi, M. J. Cowley, V. Huch and D. Scheschkewitz, Organometallics, 2013, 32, 1591-1594.

27 K. Takeuchi, M. Ichinohe and A. Sekiguchi, J. Am. Chem. Soc., 2008, 130, 16848-16849.

28 M. Ichinohe, M. Toyoshima, R. Kinjo and A. Sekiguchi, J. Am. Chem. Soc., 2003, 125, 13328-13329.

29 T. Iwamoto, M. Tamura, C. Kabuto and M. Kira, Science, 2000, 290, 504-506.

30 L. J. Schiegerl, A. J. Karttunen, W. Klein and T. F. Fässler, Chem.-Eur. J., 2018, 24, 19171-19174.

31 K. I. Leszczyńska, V. Huch, C. Präsang, J. Schwabedissen, R. J. F. Berger and D. Scheschkewitz, Angew. Chem., Int. Ed., 2019, 58, 5124-5128.

32 N. Wiberg, C. M. M. Finger and K. Polborn, Angew. Chem., Int. Ed., 1993, 32, 1054-1056.

33 T. M. Klapötke, S. K. Vasisht, G. Fischer and P. Mayer, J. Organomet. Chem., 2010, 695, 667-672.

34 T. Goebel, A. Ormeci, O. Pecher and F. Haarmann, Z. Anorg. Allg. Chem., 2012, 638, 1437-1445.

35 H. G. von Schnering, M. Schwarz, J. H. Chang, K. Peters, E. M. Peters and R. Nesper, Z. Kristallogr. - New Cryst. Struct., 2005, 220, 525.

36 L. A. Stearns, J. Gryko, J. Diefenbacher, G. K. Ramachandran and P. F. McMillan, J. Solid State Chem., 2003, 173, 251-258.

37 J. He, D. D. Klug, K. Uehara, K. F. Preston, C. I. Ratcliffe and J. S. Tse, J. Phys. Chem. B, 2001, 105, 3475-3485.

38 V. Quéneau, E. Todorov and S. C. Sevov, J. Am. Chem. Soc., 1998, 120, 3263-3264.

39 C. Hoch, M. Wendorff and C. Röhr, J. Alloys Compd., 2003, 361, 206-221.

40 K. Wade, Inorg. Nucl. Chem. Lett., 1972, 8, 559-562.

41 K. Wade, Chem. Commun., 1971, 792-793.

42 C. Lorenz, S. Gärtner and N. Korber, Z. Anorg. Allg. Chem., 2017, 643, 141-145.

43 C. B. Benda, T. Henneberger, W. Klein and T. F. Fässler, $Z$. Anorg. Allg. Chem., 2017, 643, 146-148.

44 S. Joseph, C. Suchentrunk, F. Kraus and N. Korber, Eur. J. Inorg. Chem., 2009, 2009, 4641-4647.

45 T. Henneberger, W. Klein and T. F. Fässler, Z. Anorg. Allg. Chem., 2018, 644, 1018-1027.

46 M. Waibel, F. Kraus, S. Scharfe, B. Wahl and T. F. Fässler, Angew. Chem., Int. Ed., 2010, 49, 6611-6615.

47 J. M. Goicoechea and S. C. Sevov, Organometallics, 2006, 25, 4530-4536.

48 S. Joseph, M. Hamberger, F. Mutzbauer, O. Härtl, M. Meier and N. Korber, Angew. Chem., Int. Ed., 2009, 48, 8770-8772.

49 F. S. Geitner and T. F. Fässler, Chem. Commun., 2017, 53, 12974-12977.

50 M. W. Hull and S. C. Sevov, Angew. Chem., Int. Ed., 2007, 46, 6695-6698.

51 F. Li and S. C. Sevov, Inorg. Chem., 2012, 51, 2706-2708. 
52 F. S. Geitner, J. V. Dums and T. F. Fässler, J. Am. Chem. Soc., 2017, 139, 11933-11940.

53 F. S. Geitner, W. Klein and T. F. Fässler, Angew. Chem., Int. Ed., 2018, 57, 14509-14513.

54 C. Lorenz, F. Hastreiter, J. Hioe, L. Nanjundappa, S. Gärtner, N. Korber and R. M. Gschwind, Angew. Chem., Int. Ed., 2018, 57, 12956-12960.

55 L. J. Schiegerl, A. J. Karttunen, J. Tillmann, S. Geier, G. Raudaschl-Sieber, M. Waibel and T. F. Fässler, Angew. Chem., Int. Ed., 2018, 57, 12950-12955.

56 L.-A. Jantke and T. Fässler, Inorganics, 2018, 6, 31.

57 O. Kysliak, C. Schrenk and A. Schnepf, Inorg. Chem., 2015, 54, 7083-7088.

58 L. J. Schiegerl, F. S. Geitner, C. Fischer, W. Klein and T. F. Fässler, Z. Anorg. Allg. Chem., 2016, 642, 1419-1426.

59 K. Mayer, L. J. Schiegerl, T. Kratky, S. Günther and T. F. Fässler, Chem. Commun., 2017, 53, 11798-11801.

60 K. Mayer, L. J. Schiegerl and T. F. Fässler, Chem.-Eur. J., 2016, 22, 18794-18800.

61 O. Kysliak, T. Kunz and A. Schnepf, Eur. J. Inorg. Chem., 2017, 2017, 805-810.

62 L. G. Perla and S. C. Sevov, J. Am. Chem. Soc., 2016, 138, 97959798.

63 L. G. Perla, A. Muñoz-Castro and S. C. Sevov, J. Am. Chem. Soc., 2017, 139, 15176-15181.

64 D. Nied, R. Köppe, W. Klopper, H. Schnöckel and F. Breher, J. Am. Chem. Soc., 2010, 132, 10264-10265.

65 K. Abersfelder, T.-l. Nguyen and D. Scheschkewitz, Z. Anorg. Allg. Chem., 2009, 635, 2093-2098.
66 A. Ugrinov and S. C. Sevov, Chem.-Eur. J., 2004, 10, 37273733.

67 A. J. Stone, Inorg. Chem., 1981, 20, 563-571.

68 A. J. Stone and M. J. Alderton, Inorg. Chem., 1982, 21, 22972302.

69 W. A. de Heer, Rev. Mod. Phys., 1993, 65, 611-676.

70 P. Andre Clayborne and H. Häkkinen, Phys. Chem. Chem. Phys., 2012, 14, 9311-9316.

71 N. V. Tkachenko and A. I. Boldyrev, Chem. Sci., 2019, 10, 5761-5765.

72 TURBOMOLE V7.3 2018, a development of University of Karlsruhe and Forschungszentrum Karlsruhe GmbH, 19892007, TURBOMOLE GmbH, 2007.

73 R. Ahlrichs, M. Bär, M. Häser, H. Horn and C. Kölmel, Chem. Phys. Lett., 1989, 162, 165-169.

74 J. P. Perdew, K. Burke and M. Ernzerhof, Phys. Rev. Lett., 1996, 77, 3865-3868.

75 C. Adamo and V. J. Barone, J. Chem. Phys., 1999, 110, 61586170.

76 F. Weigend and R. Ahlrichs, Phys. Chem. Chem. Phys., 2005, 7, 3297-3305.

77 G. Knizia, J. Chem. Theory Comput., 2013, 9, 4834-4843.

78 C. B. Hübschle, G. M. Sheldrick and B. Dittrich, J. Appl. Crystallogr., 2011, 44, 1281-1284.

79 Diamond Version 3.2k, Crystal Impact GbR, 1997-2014.

80 MestReNova v9.1.0, Mestrelab Research S.L., 2014.

81 WinXPOW v3.0.2.1, STOE \& Cie GmbH, 2011. 